\title{
Comparing nitrate leaching in lettuce crops cultivated under agroecological, transition, and conventional agricultural management in central Chile
}

\author{
Isabel González-Miranda $^{{ }^{*}},{\text { Kooichi } \text { Vidal }^{2} \text {, and Patricia Peñaloza }}^{2}$ \\ ${ }^{1}$ Centro Regional de Investigación e Innovación para la Sostenibilidad de la Agricultura y los Territorios Rurales (Ceres), San Francisco \\ 1600, Quillota, Chile. Corresponding author (igonzalez@ centroceres.cl). \\ 2Pontificia Universidad Católica de Valparaíso, Escuela de Agronomía, Avenida Brasil 2950, Valparaíso, Chile.
}

Received: 7 September 2020; Accepted: 27 November 2020; doi:10.4067/S0718-58392021000200210

\begin{abstract}
Nitrogen overfertilization is a common horticultural practice in central Chile, leading to the risk of nitrate leaching and contamination of aquifers and groundwater. The aim of the present study was to evaluate the effect of organic amendments on $\mathrm{NO}_{3}{ }^{-}$leaching. Three sites with different management systems were selected: Agroecological (AE, 3-yr agroecological management), Transition (TR, starting agroecological management), and Conventional (CN, traditional conventional management). Two lettuce (Lactuca sativa L.) growing cycles (autumn-winter and spring-summer) were implemented at each site. Nutrition at AE and TR was based on organic fertilizers and microorganisms, and inorganic $\mathrm{N}$ fertilizers were used at $\mathrm{CN}$. The pore water was sampled at the beginning and at the end of each cycle at the $70 \mathrm{~cm}$ depth. Lettuce yields and unit weight were measured. There was a significant effect of the site and time of sampling (both $\mathrm{p}=0.000$ ) on the $\mathrm{NO}_{3}$ concentration in leached water. At the beginning of the first cycle, nitrate leaching was 2.2 times higher at TR and CN $\left(370 \pm 81 \mathrm{mg} \mathrm{L}^{-1}\right)$ compared with AE $\left(163 \pm 54 \mathrm{mg} \mathrm{L}^{-1}\right)$, reflecting the loss of previously accumulated soil $\mathrm{N}$. Afterward, leaching at $\mathrm{CN}$ remained higher than at $\mathrm{AE}$ and $\mathrm{CN}$, significantly varying between sampling times; however, it decreased by $37 \%$ to $80 \%$ compared with the initial measurement. Leaching at both AE and TR remained stable within a low range of 38 to $96 \mathrm{mg} \mathrm{L}^{-1}$. Results showed that organic soil management is able to maintain a low rate of nitrate leaching in the soil compared with conventional management.
\end{abstract}

Key words: Inorganic fertilizers, Lactuca sativa, nitrogen, organic amendments, pore water, rhizons, soil management.

\section{INTRODUCTION}

The contamination of groundwater and aquifers due to nitrate leaching $\left(\mathrm{NO}_{3}{ }^{-}\right)$is a common phenomenon in many agricultural areas of Chile (Uribe et al., 2005). The nitrate levels in drinking water in central Chile exceed the Chilean and European Union regulations of $50 \mathrm{mg} \mathrm{L}^{-1}$; the Valparaíso Region and the Libertador General Bernardo O'Higgins Region are $4 \%$ and $10 \%$ over the limit, respectively (DCPRH, 2016a; 2016b).

An excess of $\mathrm{NO}_{3}$ in drinking water can be converted into nitrites in the gastrointestinal tract, causing methemoglobinemia in infants. There is also emerging evidence of a link to rectal, colon, and thyroid cancer in certain vulnerable human groups (Dellavalle et al., 2014).

One of the main activities that cause nitrate leaching in the soil is the excessive use of inorganic $\mathrm{N}$ fertilizers in conventional agriculture (Ahmed et al., 2019). After fertilizer application, the predominant $\mathrm{N}$ form in the soil is nitrate, which is difficult to assimilate and easily leaches unlike ammonium that is retained in soil clays (Latifah et al., 2017). In an overfertilization scenario, a residual effect is generated in the soil where excess $\mathrm{N}$ remains until it is leached out by irrigation or rainfall (Quemada et al., 2013). 
In Chile, between $75 \%$ and $90 \%$ of vegetable producers (depending on the region) use mineral sources of fertilization, mainly nitric and ammonia combinations. Due to common practices, most of these farmers apply between $20 \%$ to $47 \%$ more than the crop requirement to ensure high yields (Rojas-Walker et al., 2007).

Lettuce (Lactuca sativa L.) is one of the most overfertilized crops in Chile and the third most cultivated vegetable in the country (Rojas-Walker et al., 2007). This is likely due to the great ability of this crop to accumulate $\mathrm{N}$ in its edible tissues, and its yield and greenness have a high response to increases in N (Sylvestre et al., 2019). However, the crop has a low $\mathrm{N}$ uptake efficiency from the soil, $5 \%$ to $60 \%$ depending on the environmental conditions and its concentration due to its usually shallow root system. The crop also requires high irrigation because of its low resistance to water stress, which promotes leaching over uptake. In addition, farmers are unaware of the $\mathrm{N}$ demand curve of the crop and apply high fertilizer concentrations at the beginning of the cycle when crop demand is low (Sosa et al., 2017); this results in that some of the applied $\mathrm{N}$ remains as a residual in the soil until leaching is caused by irrigation water.

Several authors have indicated that soil nutrition through organic sources in agroecological/organic systems promotes gradual nutrient mineralization and $\mathrm{N}$ retention in the soil-plant system, thus reducing leaching. This, in addition to other advantages, such as moisture retention, increased organic matter and beneficial microorganisms. A study by Benoit et al. (2014) on 37 industrial crop farms found that the leaching rate on conventional farms was significantly higher than on organically managed farms. Jia et al. (2014) conducted controlled assays with two corn varieties by applying the 100 and $200 \mathrm{~kg} \mathrm{~N} \mathrm{ha}^{-1}$ rates using bovine manure and urea. At the same $\mathrm{N}$ application rate, leaching on urea-fertilized soils was always higher than on manure-fertilized soils, although the yields on manure treatments were $0.5 \%$ to $5.0 \%$ lower. Daza et al. (2015) carried out a study with lysimeters in stevia crops using ammonium sulfate vs. manure and vermicompost. The organic fertilizers reduced nitrate leaching by $75 \%$ to $99 \%$ at the $30 \mathrm{~cm}$ depth compared with ammonium sulfate.

Although there is research on the topic, the evidence is not entirely consistent. Internationally, most studies on nitrate leaching have been conducted on industrial crops (Jia et al., 2014; Tosti et al., 2016), and there is limited information for vegetables. Furthermore, some authors have observed that it is not possible to ensure that organic nutrition generates less $\mathrm{N}$ leaching than inorganic nutrition for the same yield. This is due to the slow release of $\mathrm{N}$ that sometimes does not coincide with the stages of higher $\mathrm{N}$ uptake by the crops, increasing leaching (Kirchmann and Bergström, 2001). Research on fertilization management to reduce leaching is very limited in Chile, and it is also focused on industrial crops (Claret et al., 2011; Salazar et al., 2019). This suggests the need for further research by extending studies to the important vegetables consumed in the country.

The objective of the present study was to compare nitrate leaching under similar $\mathrm{N}$ inputs adjusted to crop and soil requirements in a production system under conventional management with inorganic fertilizers compared with a system with traditional agroecological management and another with agroecological transition; these last two sites used only organic fertilizers. The crop chosen for this study was lettuce because of its importance in Chilean horticulture and the common practice of overfertilization leading to health problems. The study was conducted in two growing seasons, autumn-winter and spring-summer. This work is part of a broader research study that aims to study the environmental and productive benefits of horticultural systems under agroecological management.

\section{MATERIALS AND METHODS}

The research was carried out in Quillota (32 $53^{\prime} \mathrm{S}, 71^{\circ} 12^{\prime} \mathrm{W}$ ), Valparaiso Region, Chile. The area has a warm summer Mediterranean climate (Csb) according to the Köppen classification, and the $236 \mathrm{~mm}$ annual rainfall (10-yr mean) is concentrated in the winter months.

Three sites of $250 \mathrm{~m}^{2}$ each were selected under three different management systems. First, the Agroecological (AE) site was under agroecological management for $3 \mathrm{yr}$; it was previously cultivated with the rotation and association of vegetables, organic fertilizers added to the soil, and an environment with diverse cultivated and wild species. The Transition (TR) site was previously used for vegetables under a conventional management system, but organic soil management was initiated for the purposes of this study and agrochemicals were eliminated. Finally, the Conventional (CN) site was previously under conventional management, and we continued applying a conventional fertilization package adjusted to the crop.

The CN and TR sites are neighboring farms that were traditionally used for horticulture under intensive conventional management practices with high pesticide and chemical fertilizer use, although these were in disuse for 6 mo prior to the 
experiments. Large amounts of manure were usually applied at these sites at the beginning of each crop. Both sites are surrounded by a monoculture of brassicas and 50 ha of avocado and lemon trees, which are under intensive conventional management. The AE site is located $400 \mathrm{~m}$ north of the other two sites. The soil is similar at the three sites: Hijuelas series, fine loamy, mixed, thermic family, which is of alluvial sedimentary origin, Mollisols, loam to sandy loam, with a depth greater than $2 \mathrm{~m}$, and $1 \%$ to $2 \%$ slope. The soil use capacity is Class II for soils with slight limitations (CIREN, 2009).

Five soil samples of $0.5 \mathrm{~kg}$ at the 0 to $30 \mathrm{~cm}$ depth were randomly taken at each site at the beginning and end of the assays. Organic matter, $\mathrm{pH}$, conductivity, N, P, and $\mathrm{K}$ were determined in the laboratory based on methods described by Sadzawka et al. (2006).

A quasi-experimental design was defined in which each site with different soil management corresponded to one treatment. Nine experimental units (seedbeds) were established at each site. The design was defined in this way because the treatments considered traditional soil management that could not be spatially randomized and existed prior to beginning the assay.

\section{Lettuce cultivation and soil management}

Two growth cycles of lettuce cultivation were implemented over an 8-mo period at the three study sites. The first cycle, autumn-winter, was established from June to October 2018 (105 d from transplant to harvest) with Iceberg type lettuce (Lactuca sativa L. var. capitata L., 'Desert Storm'). The second cycle, spring-summer, was established from November to December 2018 (42 d from transplant to harvest) with Milanese type lettuce (L. sativa L., 'Victoriosa'). Both varieties are widely used in central Chile during these cycles. The crops were established on $15 \times 1 \mathrm{~m}^{2}$ seedbeds in a $30 \times 30 \mathrm{~cm}^{2}$ planting frame for Iceberg lettuce and $25 \times 25 \mathrm{~cm}^{2}$ for Milanese lettuce using a drip irrigation system. A total of 1500 lettuce plantlets were transplanted in the first cycle and 2160 in the second cycle.

Fertilization was adjusted at all three sites to the soil nutrient content (Table 1) and the nutritional absorption curve of the crop (based on Sosa et al., 2017) with the aim of obtaining equivalent yields. The estimate for organic fertilizers was based on the available $\mathrm{N}$ contained in the products before application and a standard rate of $35 \%$ mineralization per year obtained from the literature (Antoniadis, 2013). In the first cycle, $200 \mathrm{t} \mathrm{ha}^{-1}$ composted goat and sheep manure $\left(3 \mathrm{t} \mathrm{N} \mathrm{ha}^{-1}\right.$ ) was applied at the AE site and incorporated in the first $20 \mathrm{~cm}$ of soil. Given the high initial N levels at TR, only $1 \mathrm{t} \mathrm{ha}^{-1}$ of guano was applied aimed at providing approximately $15 \mathrm{~kg} \mathrm{~N} \mathrm{Na}^{-1}$ organic matter. Initial $\mathrm{N}$ was also high at $\mathrm{CN}$ and only $80 \mathrm{~kg} \mathrm{ha}^{-1}$ of 15-30-15 NPK fertilizer (Initial Ultrasol, Soquimich, Santiago, Chile) was applied by fertigation $\left(12 \mathrm{~kg} \mathrm{~N} \mathrm{ha}^{-1}\right)$ at the beginning of the crop.

Table 1. Chemical characteristics of soils under three different site management (SM) practices at three sampling times $(\mathbf{n}=5)$.

\begin{tabular}{|c|c|c|c|c|c|c|}
\hline & & $\mathrm{CE}$ & $\mathrm{OM}$ & Available N & Available P & Available K \\
\hline SM & $\mathrm{pH}$ & $\mathrm{dS} \mathrm{m} \mathrm{m}^{-1}$ & $\%$ & & $\mathrm{mg} \mathrm{kg}^{-1}$ & \\
\hline \multicolumn{7}{|c|}{ Beginning autumn-winter cycle } \\
\hline $\mathrm{AE}$ & $7.9 \pm 0.16 \mathrm{aA}$ & $2.9 \pm 0.54 \mathrm{aA}$ & $3.1 \pm 0.37 \mathrm{bA}$ & $30.4 \pm 12.7 \mathrm{cA}$ & $89.8 \pm 6.4 \mathrm{bA}$ & $355.2 \pm 97 \mathrm{cB}$ \\
\hline TR & $8.3 \pm 0.07 \mathrm{bA}$ & $3.7 \pm 1.02 \mathrm{aA}$ & $5.4 \pm 1.27 \mathrm{aA}$ & $142.8 \pm 51.8 \mathrm{aA}$ & $186.2 \pm 42.2 \mathrm{aA}$ & $957.8 \pm 257 \mathrm{aA}$ \\
\hline $\mathrm{CN}$ & $8.3 \pm 0.07 \mathrm{bA}$ & $3.0 \pm 0.64 \mathrm{aA}$ & $4.1 \pm 0.66 \mathrm{abA}$ & $105.9 \pm 34.4 \mathrm{bA}$ & $101.7 \pm 13.7 \mathrm{bB}$ & $632.2 \pm 202 \mathrm{bA}$ \\
\hline \multicolumn{7}{|c|}{ End of autumn-winter cycle, beginning of spring-summer cycle } \\
\hline $\mathrm{AE}$ & $8.3 \pm 0.21 \mathrm{aA}$ & $2.0 \pm 0.53 \mathrm{aB}$ & $3.6 \pm 0.81 \mathrm{bA}$ & $29.9 \pm 8.1 \mathrm{abA}$ & $113.8 \pm 60.8 \mathrm{bA}$ & $487.9 \pm 175 \mathrm{aAB}$ \\
\hline TR & $8.2 \pm 0.16 \mathrm{aA}$ & $1.9 \pm 0.36 \mathrm{aB}$ & $5.3 \pm 1.57 \mathrm{aA}$ & $42.5 \pm 12.4 \mathrm{aB}$ & $164.6 \pm 61.3 \mathrm{aA}$ & $331.7 \pm 84 \mathrm{bB}$ \\
\hline $\mathrm{CN}$ & $7.9 \pm 1.88 \mathrm{aA}$ & $1.4 \pm 0.28 \mathrm{bB}$ & $4.3 \pm 0.81 \mathrm{bA}$ & $21.6 \pm 12.0 \mathrm{bC}$ & $137.7 \pm 55.0 \mathrm{aAB}$ & $327.0 \pm 70 \mathrm{bB}$ \\
\hline \multicolumn{7}{|c|}{ End of spring-summer cycle } \\
\hline $\mathrm{AE}$ & $8.1 \pm 0.11 \mathrm{aA}$ & $3.2 \pm 0.75 \mathrm{aA}$ & $4.4 \pm 0.39 \mathrm{aA}$ & $33.0 \pm 13.0 \mathrm{aA}$ & $143.7 \pm 15.6 \mathrm{aA}$ & $623.0 \pm 135 \mathrm{aA}$ \\
\hline TR & $8.2 \pm 0.05 \mathrm{aA}$ & $2.6 \pm 0.47 \mathrm{aB}$ & $5.2 \pm 0.74 \mathrm{aA}$ & $25.3 \pm 2.6 \mathrm{aB}$ & $205.6 \pm 75.0 \mathrm{aA}$ & $244.3 \pm 36 \mathrm{bAB}$ \\
\hline $\mathrm{CN}$ & $8.2 \pm 0.12 \mathrm{aA}$ & $2.6 \pm 0.73 \mathrm{aA}$ & $4.4 \pm 0.73 \mathrm{aA}$ & $43.1 \pm 18.9 \mathrm{aB}$ & $180.6 \pm 49.6 \mathrm{aA}$ & $613.5 \pm 155 \mathrm{aA}$ \\
\hline
\end{tabular}

Different lowercase letters in the same column for the same sampling time indicate differences between sites for the variable. Different uppercase letters in the columns for the same site indicate differences between sampling times for the variable. The soil samples were taken at a 0-30 cm depth.

CE: Electrical conductivity; OM: organic matter; AE: agroecological management; TR: transition management; CN: conventional management. 
In the second cycle, $350 \mathrm{t} \mathrm{ha}^{-1}$ of commercial base compost (Vuelta Verde, Santiago, Chile; ratio C/N 15.4; $2.6 \mathrm{t} \mathrm{N} \mathrm{ha}^{-1}$ ) was applied at the AE and TR sites and a decomposition and mineralization accelerator $\left(800 \mathrm{~L} \mathrm{ha}^{-1}\right.$; Biolux, Helénica, Quillota, Chile) composed of various microorganisms (Bacillus sp., filamentous fungi, and yeasts) was applied 4 and 6 wk later, respectively. This application considers a short growth cycle crop with high nutritional requirements, which coincided with the summer season when the species has the maximum nutritional requirements (Bugarín-Montoya et al., 2011). At the CN site, $764 \mathrm{~kg} \mathrm{ha}^{-1}$ of Initial Ultrasol (15-30-15 NPK) was applied and subsequently $440 \mathrm{~kg} \mathrm{ha}^{-1}$ of Growth Ultrasol (25-10-10 NPK) by fertigation, which was divided in the recommended weekly applications, to make crop nutrition more efficient.

Irrigation was the same at all three sites. In the first cycle, $407 \mathrm{~mm}$ irrigation was applied and there was $53 \mathrm{~mm}$ rainfall. In the second cycle, $224 \mathrm{~mm}$ irrigation was applied and there was no rainfall. System precipitation was $16.6 \mathrm{~mm} \mathrm{~h}^{-1}$.

No phytosanitary control products were applied at any of the three sites because the macro research study in which the assays were conducted was aimed at determining the natural incidence of pests and diseases.

Temperature was measured by sensors (Pro v2, HOBO, Onset, Cape Cod, Massachusetts, USA) at each site, which was 6 to $28{ }^{\circ} \mathrm{C}$ with a mean of $11.6{ }^{\circ} \mathrm{C}$ and $86 \%$ mean relative humidity for the first cycle. In the second cycle, temperature ranged from 7 to $38^{\circ} \mathrm{C}$ with a daily mean of $18.5^{\circ} \mathrm{C}$ and $71 \%$ mean relative humidity.

\section{Nitrate measurement}

Nitrate sampling was performed at the beginning ( $15 \mathrm{~d}$ after transplanting) and end ( 3 to $5 \mathrm{~d}$ before harvest) of each lettuce growing cycle at each site. For this purpose, nine pore water collection kits or MacroRhizons (Rhizosphere, Wageningen, The Netherlands) were installed at each site, one for each seedbed (experimental unit). The equipment was inserted after transplanting at a $70 \mathrm{~cm}$ depth under the central row of each seedbed by digging a hole diagonally $\left(45^{\circ}\right.$ angle $)$ from one side of the seedbed (Figure 1), following the manufacturer's instructions.

Leachate collection began $4 \mathrm{~h}$ after irrigation with $25 \mathrm{~mm}$ syringes attached to the MacroRhizons using luer locks. The syringes were maintained for 4 to $6 \mathrm{~h}$ until filled with pore water (following the methodology described by Kabala et al., 2014). Afterward, syringes were decoupled from the MacroRhizons and collected water was transferred to a sealed plastic bottle and immediately taken to the laboratory. Nitrate indicator strips (Merckoquant test strips, Merck, Darmstadt, Germany) were immersed in the water samples for 1 to $2 \mathrm{~s}$ and then inserted in a portable refractometer (Nitracheck 404, KPG Products Ltd., Hove, UK) to determine the nitrate concentration by colorimetry. Two subsamples were measured, and the measurement was repeated if the difference was greater than $20 \%$.

\section{Total yield and unit weight measurement}

Yield per surface area was determined at each site and in each cycle to ensure that fertilization was adequate; therefore, nitrate leaching was evaluated on the basis of similar yields for the different sites. All lettuce units at each site were harvested, counted, and weighed. Harvested lettuce heads whose unit weight was below the commercial lower limit (based on Saavedra et al., 2017) were rejected along with those affected by pests and diseases to the extent of not being marketable.

Figure 1. Diagram of the insertion of the MacroRhizons in the leaching zone under the seedbed.

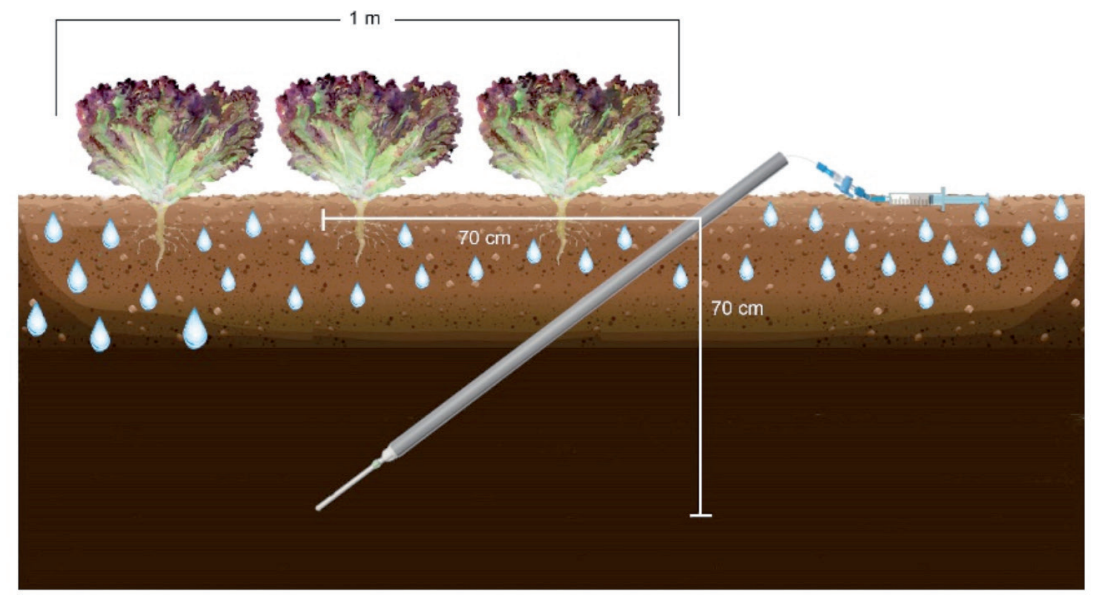




\section{Statistical analysis}

To compare the three sites for the initial soil chemical variables ( $\mathrm{pH}$, organic matter, conductivity, $\mathrm{N}, \mathrm{K}$, and available $\mathrm{P}$ ), a repeated measures ANOVA was performed after checking the normality of the response variable and considering "sampling time" as the within-subjects factor and "site" as the between-subjects factor. If differences between sites or sampling times were found, Tukey's test at 0.05 confidence interval was performed to identify the differences between groups.

The yields of each cycle were analyzed separately because lettuce varieties differed and were grown in different seasons. A one-way ANOVA was performed in each cycle to detect differences between the sites with different management as a fixed factor and after checking the response variable for normality. If differences were found, Tukey's post-hoc test at 0.05 confidence was performed.

The $\mathrm{NO}_{3}{ }^{-}$leaching data exhibited a log-normal distribution. Data were therefore transformed to achieve normality. Data from the three sites and four sampling times were analyzed by a repeated measure ANOVA with specifications similar to those for soil analysis. If significant differences were found between sites and/or between sampling times, Tukey's post-hoc test at 0.05 confidence interval was performed. The analyses were performed with SPSS Software (IBM, Armonk, New York, USA) version 20.

\section{RESULTS AND DISCUSSION}

\section{Physical-chemical characteristics of soils at the beginning of the study}

At the beginning of the study, $\mathrm{pH}$ was moderately alkaline at all three sites (based on the classification by Flynn, 2015), which is consistent with other studies for soils at this location (Fuentes et al., 2015) (Table 1).

Conductivity values showed that soils were moderately saline at all three sites (Table 1). The organic matter content was very high at the three sites, which indicates past applications at the three sites. As for macronutrients, and following Flynn's interpretation table (Flynn, 2015), available N content in AE was sufficient for most crops, while it was significantly higher and classified as excessive in TR and $\mathrm{CN}$, which was likely due to residues from intensive fertilization of previous crops grown during the last summer season, a period with no rainfall that could mobilize these compounds in the soil profile. The concentration of available $\mathrm{P}$ was excessive at all three sites, although it was significantly higher in TR than at the other two sites. The $\mathrm{K}$ concentration in $\mathrm{AE}$ and $\mathrm{CN}$ was sufficient, while it was significantly higher and classified as excessive in TR. These high K concentrations were expected because it is a characteristic of soils from alluvial sediments (Ruiz and Araos, 1978). At the end of the assays, most of the soil physical-chemical characteristics were maintained, except for the $\mathrm{N}$ concentration, which decreased significantly to suitable values in $\mathrm{CN}$ and $\mathrm{TR}$.

\section{Yields}

In the first cycle of $115 \mathrm{~d}$, the yield per surface at the TR and $\mathrm{CN}$ sites was similar $(\mathrm{p}=0.116)$. However, it was significantly lower at $\mathrm{AE}(\mathrm{p}=0.000)$, which was $37 \%$ less than the mean yield at the other two sites (Figure $2 \mathrm{~A})$. This low yield per unit area is mainly explained by a $68 \%$ rejection of lettuce units at AE $v s .30 \%$ on average at TR and CN (data not shown). This rejection was due to a fungal disease outbreak (Botrytis cinerea) that caused leaf necrosis, thus preventing their commercialization or causing the early death of some individuals. Given that disease control products were not applied at any of the three sites and that the first cycle took place in an environment with high humidity and weak to moderate rainfall cycles, conditions were susceptible to the appearance of fungal disease (Saavedra et al., 2017). The difference between sites can be because AE was cultivated before this study and the preceding crops could have left the inoculum, unlike the other two sites that were no used for 6 mo prior to the beginning of the assays. In addition, the AE seedbeds were surrounded by flower beds containing Brassicaceae family species, which can harbor disease inoculum that affect lettuce leaves (Byron et al., 2019). The CN and TR sites had no wild vegetation around the crop and were surrounded by fruit trees and brassica crops with high agrochemical loads (fertilizers, fungicides, and pesticides), which could inhibit inoculum spread or even reach the crop by drift (Fishel and Ferrell, 2010), thus exerting a direct control effect.

A nutritional deficiency of $\mathrm{P}, \mathrm{K}$, and micronutrients such as $\mathrm{Cl}$ and $\mathrm{Si}$ could make crops more susceptible to a severe attack of certain fungal diseases, thus promoting their establishment in the plant and their propagation (Walters and Bingham, 2007). A low mineralization rate of the soil organic matter at $\mathrm{AE}$ this could have caused a deficit of nutrients for the crop. However, based on the reported data, this possibility can neither be confirmed nor ruled out. It is therefore necessary to analyze the results obtained for lettuce unit weight. If the scenario of nutritional deficit were real, it would be expected that mean lettuce weight at $\mathrm{AE}$ would be lower than at the other two sites. 
Figure 2. Lettuce crop yield for three different site management practices in the autumn-winter cycle (A) and springsummer cycle $(B)$.
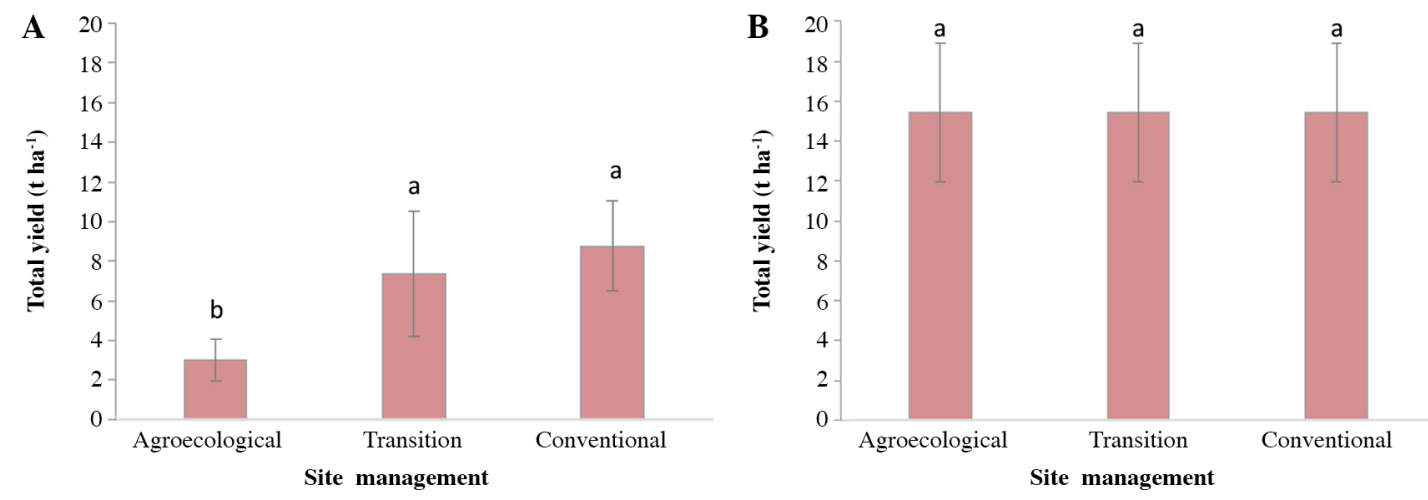

Means $(\mathrm{n}=9)$ and standard deviation (error bars) are shown. Different letters indicate differences between sites according to Tukey's test $(\mathrm{p}<0.05)$.

The second cycle was much shorter than the first, but yields were similar between the three sites $(\mathrm{p}=0.761$, Figure 2B) with an $11 \%$ general rejection rate associated with common production problems, such as irrigation problems that affected the unit weight of some units, damage by predators (birds, rodents, rabbits), and premature flowering due to high temperatures. No diseases were detected, which was probably due to the period being characterized by low humidity and high temperatures. The results for the second cycle allow us to infer that the contribution of nutrients in this cycle was similar at the three sites.

\section{Lettuce unit weight}

Regarding the weight of the harvested commercial lettuce units, these were similar between the three study sites for both cycles ( $p=0.234$ for cycle $1 ; p=0.916$ for cycle 2 , Figure 3 ). In the first cycle, unit weight was within the expected range for 'Desert Storm' (0.9 to $1.1 \mathrm{~kg}$ according to Contreras et al., 2017). The adequate unit weight of the harvested units allows us to infer that the highest incidence of diseases at $\mathrm{AE}$ in the first cycle was not due to a nutritional deficit. In the second cycle, the lettuce unit weight at AE and TR was slightly lower (6\% to 9\%) than the 0.45 to $0.55 \mathrm{~kg}$ expected for 'Victorious' according to Anasac (2016). The cause could be only a problem with the irrigation system, which occurred 2 wk before harvest and reduced optimal irrigation in one seedbed for $2 \mathrm{~d}$.

Notwithstanding the specific problems that reduced yield and lettuce unit weight, the overall results indicated that nutrition at all three sites was according to crop requirements, which allows comparing nitrate leaching.

Figure 3. Unit fresh weight of Milanese lettuce for three different site management practices in the autumn-winter (A) and spring-summer (B) cycles.
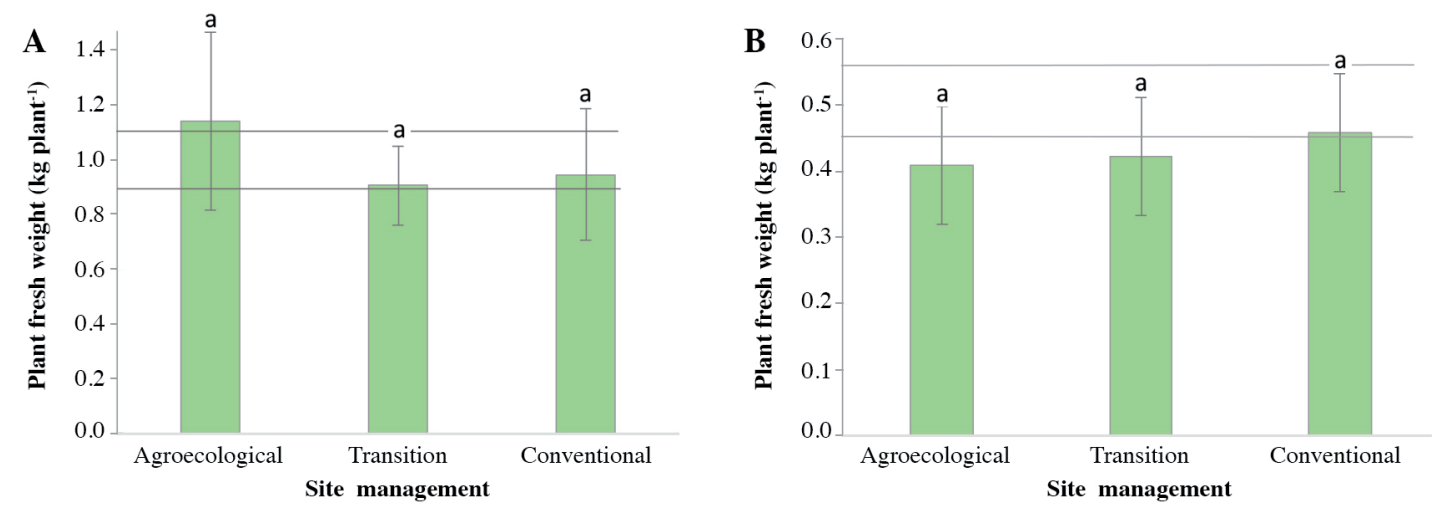

Means $(\mathrm{n}=9)$ and standard deviation (error bars) are shown.

Expected unit weight range for the studied varieties based on previous technical reports or commercial records is shown between horizontal lines; Contreras et al. (2017) for A and Anasac (2016) for B.

Same letters indicate nonsignificant differences between sites according to Tukey's test $(\mathrm{p}<0.05)$. 


\section{Nitrate leaching}

There were significant differences in nitrate leaching between the three study sites and four sampling times (both with $\mathrm{p}=0.000)$.

At the beginning of the first cycle (autumn-winter), the concentration of $\mathrm{NO}_{3}{ }^{-}$in the leached water was significantly higher at $\mathrm{CN}$ and TR (mean $370 \pm 81 \mathrm{mg} \mathrm{L}^{-1}$ ) compared with AE $\left(164 \pm 54 \mathrm{mg} \mathrm{L}^{-1}\right)$ (Figure 4). This is explained by the excessive concentration of soil residual $\mathrm{N}$ at $\mathrm{CN}$ and TR at the beginning of the assays (Table 1). It was rapidly leached by irrigation and rain ( $4 \mathrm{~mm}$ rainfall in sampling week) because it corresponds to soluble forms. This coincides with other studies; for example, Beckwith et al. (1998) demonstrated that at a site under organic nutrition, residual soil $\mathrm{N}$ from previous intensive cultivation, generated a high $\mathrm{N}$ concentration in the leachate, even after a winter fallow, which exceeded the prevailing regulations in the country under study. This fact is of environmental concern because it shows that the high concentrations of residual soil nitrates under traditional conventional management could contaminate groundwater during rain events.

Therefore, the $\mathrm{NO}_{3}{ }^{-}$concentrations in the leachate at the three sites at the end of the first cycle were significantly lower than their initial concentrations and were similar (mean $44.6 \pm 7.5 \mathrm{mg} \mathrm{L}^{-1}$ ); these values are within the limits of nitrate concentration in drinking water established by the European Union $\left(50 \mathrm{mg} \mathrm{L}^{-1}\right)$. This decrease reflects the loss of soil $\mathrm{N}$ during the cycle through crop uptake and leaching of residual $\mathrm{N}$. At the $\mathrm{CN}$ and TR sites, this decrease was $87 \%$ on average, which shows that the excess soil residual $\mathrm{N}$ was "cleaned" from the soil during the cycle. This "cleaning" process is reflected in the significant decrease in soil $\mathrm{N}$, ranging from excessive values to values considered sufficient (Table 1) toward the end of this cycle.

At the beginning of the second cycle, the concentration of $\mathrm{NO}_{3}{ }^{-}$in the leachate increased at all three sites compared with the end of the first cycle ( 0.8 to 3.6 times, Figure 2). This was expected given the new application of $\mathrm{N}$ sources for crop nutrition carried out at all three sites. At that time, leachate $\mathrm{NO}_{3}$ concentration $\left(202 \pm 70 \mathrm{mg} \mathrm{L}^{-1}\right)$ at $\mathrm{CN}$ was significantly higher than at the other two sites (mean $92 \pm 45 \mathrm{mg} \mathrm{L}^{-1}$ ), and was similar to the initial concentration for the first cycle at this site; values were higher than those recommended by international standards (European Union, $50 \mathrm{mg} \mathrm{L}^{-1}$ ). This is probably associated with the soluble nature of the fertilizers applied at this site ( $2 \mathrm{~d}$ prior to sampling), which leach rapidly, unlike $\mathrm{N}$ supplied through compost at AE and TR, which is gradually mineralized. These differences in leaching in soil with organic $v s$. inorganic nutrition are similar to the results of other studies such as Daza et al. (2015). The concentration of $\mathrm{NO}_{3}{ }^{-}$at the beginning of the second cycle at TR was $79 \%$ lower than the concentration at the beginning of the first cycle due to the "cleaning" process of the site.

Figure 4. Nitrate leaching for three different site management practices and time of sampling in each cycle.

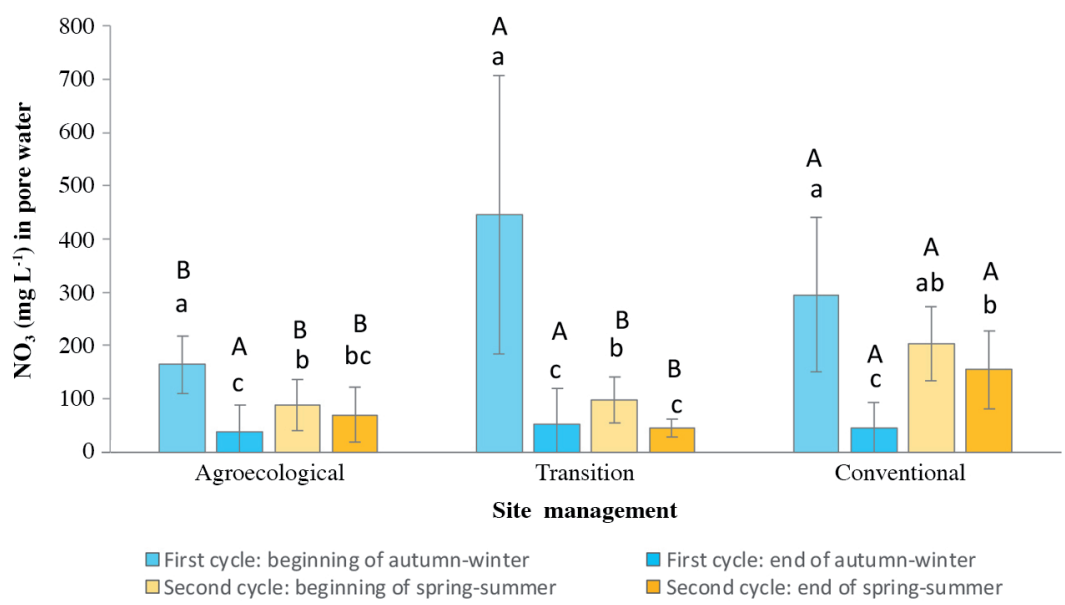

Means $(\mathrm{n}=9)$ and standard deviation (error bars) are shown. Different lowercase letters at the same site indicate differences between sampling times according to Tukey's test $(\mathrm{p}<0.05)$. Different uppercase letters for the same sampling time indicate differences between sites according to Tukey's test $(p<0.05)$. 
At the end of the second cycle, the $\mathrm{NO}_{3}{ }^{-}$concentration in the leachate was significantly higher at $\mathrm{CN}\left(154 \pm 70 \mathrm{mg} \mathrm{L}^{-1}\right)$ compared with TR and AE (mean $53 \pm 31 \mathrm{mg} \mathrm{L}^{-1}$ ). The value was also similar to the initial value in the same cycle at $\mathrm{CN}$. This could be due to gradual fertilizer application according to the established program, which kept the concentration of soil soluble $\mathrm{N}$ constant. In conventional fertilization programs, the common practice is to not apply fertilizers in the last week because the crop absorption curve is stabilized. However, harvest in this cycle occurred $1 \mathrm{wk}$ ahead of the planned date (at the three sites) due to high temperatures in December (mean $18^{\circ} \mathrm{C}$, maximum $33^{\circ} \mathrm{C}$ ), which accelerated plant development. Consequently, the last planned fertilization was applied only $4 \mathrm{~d}$ before harvest. This could generate high residual soil $\mathrm{N}$ when nitrate was measured. Several authors recognize that, although the first factor affecting nitrate leaching is the applied fertilizer rate, timing of the application of such fertilizers also affects it significantly in different crops (Delin and Stenberg, 2014).

In addition, at the end of the second cycle, the $\mathrm{NO}_{3}{ }^{-}$concentration in the leachate at $\mathrm{AE}$ and $\mathrm{TR}$ were similar. The concentration at AE did not significantly decrease compared with the beginning of the same cycle. This could be due to gradual $\mathrm{N}$ mineralization from compost at a rate equivalent to crop absorption, which allowed the crop to be efficiently nourished and maintain low $\mathrm{N}$ mobility in the profile. In contrast, the reduction in $\mathrm{NO}_{3}$ - concentration at TR between the beginning and end of the second cycle was significant (64\% less). The cause is difficult to establish, but it could be attributed to a lower rate of mineralization at this site compared with $\mathrm{AE}$, which resulted in the crop consuming a higher proportion of solubilized N. Although the same amendment and product based on microorganisms were applied at TR and $\mathrm{AE}$, the diversity and amount of microorganisms initially present in the soil were probably less at TR because of the previous intensive conventional management. This belief has been reported by several authors (e.g., Paolini Gómez, 2018).

Analyzing the evolution of the data at each site, the values at $\mathrm{CN}$ were generally higher than at $\mathrm{TR}$ and $\mathrm{AE}$, and values exceeded those recommended by the prevailing regulations. Although there were variations between sampling times, the $\mathrm{NO}_{3}{ }^{-}$concentration in the leachate remained between $37 \%$ and $80 \%$ below the initial value after the first measurement at the beginning of the first cycle.

Likewise, at both the TR and AE sites, nitrate concentration values remained stable and similar at both sites after the first measurement with mean values ranging from 38 to $96 \mathrm{mg} \mathrm{L}^{-1}$. Although these values were to some extent higher than the European standard, they should be interpreted as subsurface values that decrease further down in the soil profile.

This result shows the comparative benefits of organic soil nutrition because it was possible to obtain commercial yields and unit weights similar to those at the $\mathrm{CN}$ site and with no risk of groundwater contamination at the beginning or end of the cultivation cycle.

It is generally recommended to conduct longer assays (e.g., more than one winter) and with intermediate sampling periods to evaluate and compare the leaching rate associated with each fertilizer application time and rainfall scenarios. This can also be associated with the existing microbial biomass or with soil respiration, which allows to accurately compare nutrient availability with the mineralization rates in sites with organic amendments.

\section{CONCLUSIONS}

The present study showed that, at equivalent $\mathrm{N}$ rates applied to the crops, organic soil nutrition is able to maintain comparatively low levels of nitrate leaching in the soil during cultivation, which is probably due to gradual nutrient mineralization by microorganisms.

It also shows that in soils with a high residual $\mathrm{N}$ due to the traditional application of inorganic fertilizers, it is quickly leached with the entry of water into the soil profile. This is an issue of environmental concern because $\mathrm{N}$ can contaminate groundwater. Finally, it was also observed that an inorganic fertilization program adjusted to the soil and needs of the crop, with gradual fertilizer applications, generated variable nitrate leaching, generally higher than nitrate leaching at the sites with agroecological management. However, this adjusted fertilization program allowed the decrease of residual $\mathrm{N}$ that was initially in the soil due to traditional conventional fertilization. 


\section{ACKNOWLEDGEMENTS}

This study was supported by the CONICYT REGIONAL/Ceres/R15A10001 grant and by the CONICYT REGIONAL/ R17F10006 grant. The author wishes to thank José Dávila, Tamara Donoso, and Emiliano González for their technical assistance.

\section{REFERENCES}

Ahmed, N., Bodrud-Doza, M., Islam, A.R.M., Hossain, S., Moniruzzaman, M., Deb, N., et al. 2019. Appraising spatial variations of $\mathrm{As}, \mathrm{Fe}, \mathrm{Mn}$ and $\mathrm{NO}_{3}$ contaminations associated health risks of drinking water from Surma basin, Bangladesh. Chemosphere 218:726-740.

Anasac. 2016. Semillas de lechuga. Anasac, Providencia, Chile. Available at https://www.anasac.cl/agropecuario/wp-content/ uploads/Folleto_Lechugas.pdf (accessed 21 November 2020).

Antoniadis, V. 2013. Mineralization of organic-amendment-derived nitrogen in two Mediterranean soils with different organicmatter contents. Communications in Soil Science and Plant Analysis 44:2788-2795.

Beckwith, C.P., Cooper, J., Smith, K.A., and Shepherd, M.A. 1998. Nitrate leaching loss following application of organic manures to sandy soils in arable cropping. Soil Use and Management 14:123-130.

Benoit, M., Garnier, J., Anglade, J., and Billen, G. 2014. Nitrate leaching from organic and conventional arable crop farms in the Seine Basin (France). Nutrient Cycling in Agroecosystems 100:285-299.

Bugarín-Montoya, R., Virgen-Ponce, M., Galvis-Spinola, A., García-Paredes, D., Hernández-Mendoza, T., Bojorquez-Serrano, I., et al. 2011. Extracción de nitrógeno en seis especies olerícolas durante su ciclo de crecimiento. Bioagro 23:93-98.

Byron, M., Treadwell, D., and Dittmar, P. 2019. Weeds as reservoirs of plant pathogens affecting economically important crops. University of Florida, Gainesville, Florida, USA.

CIREN. 2009. Estudio agrológico V Región. Descripciones de Suelos. Materiales y Símbolos. Actualización 2009. Centro de Información de Recursos Naturales (CIREN), Santiago, Chile.

Claret, M., Urrutia, R., Ortega, R., Best, S., and Valderrama, N. 2011. Quantifying nitrate leaching in irrigated wheat with different nitrogen fertilization strategies in an Alfisol. Chilean Journal of Agricultural Research 71:148-156.

Contreras, C., Muñoz, L., e Ibacache, G. 2017. Manejo del riego en el cultivo de lechuga en dos épocas de siembra en el sector Pan Azúcar, Región de Coquimbo. Informativo INIA N68. 4 p. Instituto de Investigaciones Agropecuarias (INIA), La Serena, Chile.

Daza, M., Díaz, J., Aguirre, E., y Urrutia, N. 2015. Efecto de abonos de liberación lenta en la lixiviación de nitratos y nutrición nitrogenada en estevia. Revista Colombiana de Ciencias Hortícolas 9:112-123.

DCPRH. 2016a. Diagnóstico de la calidad de las aguas subterráneas de la Región de Valparaíso. Departamento de Conservación y Protección de Recursos Hídricos (DCPRH), Dirección General de Aguas (DGA), Ministerio de Obras Públicas (MOP), Santiago, Chile.

DCPRH. 2016b. Diagnóstico de la calidad de las aguas subterráneas de la Región Lib. Bernardo O’Higgins. Departamento de Conservación y Protección de Recursos Hídricos (DCPRH), Dirección General de Aguas (DGA), Ministerio de Obras Públicas (MOP), Santiago, Chile.

Delin, S., and Stenberg, M. 2014. Effect of nitrogen fertilization on nitrate leaching in relation to grain yield response on loamy sand in Sweden. European Journal of Agronomy 52:291-296.

Dellavalle, C.T., Xiao, Q., Yang, G., Shu, X.-O., Aschebrook-Kilfoy, B., Zheng, W., et al. 2014. Dietary nitrate and nitrite intake and risk of colorectal cancer in the Shanghai Women's Health Study. International Journal of Cancer 134:2917-2926.

Fishel, F., and Ferrell, A. 2010. Managing pesticide drift. Institute of Food and Agricultural Sciences (IFAS) Extension, University of Florida, Florida, USA.

Flynn, R. 2015. Interpreting soil test: unlock the secrets of your soil. New Mexico State University, Las Cruces, New Mexico, USA. Available at https://aces.nmsu.edu/pubs/_circulars/CR676/welcome.html (accessed 12 June 2020).

Fuentes, S., Ding, G.-C., Cárdenas, F., Smalla, K., and Seeger, M. 2015. Assessing environmental drivers of microbial communities in estuarine soils of the Aconcagua River in Central Chile. FEMS Microbiology Ecology 91(10):fiv110.

Jia, X., Shao, L., Liu, P., Zhao, B., Gu, L., Dong, S., et al. 2014. Effect of different nitrogen and irrigation treatments on yield and nitrate leaching of summer maize (Zea mays L.) under lysimeter conditions. Agricultural Water Management 137:92-103.

Kabala,C., Karczewska,A., and Medynska-Juraszek,A. 2014. Variability and relationships between $\mathrm{Pb}, \mathrm{Cu}$, and Zn concentrations in soil solutions and forest floor leachates at heavily polluted sites. Journal of Plant Nutrition and Soil Science 177:573-584.

Kirchmann, H., and Bergström, L. 2001. Do organic farming practices reduce nitrate leaching? Communications in Soil Science and Plant Analysis 32:997-1028.

Latifah, O., Ahmed, O.H., and Abdul Majid, N.M. 2017. Enhancing nitrogen availability, ammonium adsorption-desorption, and soil pH buffering capacity using composted paddy husk. Eurasian Soil Science 50:1483-1493. 
Paolini Gómez, J.E. 2018. Actividad microbiológica y biomasa microbiana en suelos cafetaleros de los Andes venezolanos. Terra Latinoamericana 36:13-22.

Quemada, M., Baranski, M., Nobel-de Lange, M.N.J., Vallejo, A., and Cooper, J.M. 2013. Meta-analysis of strategies to control nitrate leaching in irrigated agricultural systems and their effects on crop yield. Agriculture, Ecosystems and Environment 174:1-10.

Rojas-Walker, C., Chacón, A., Moyano, S., Estay, P., Sepúlveda, J., Ormeño, J., et al. 2007. Manejo de agroquímicos en sistemas hortícolas. Boletín INIA N${ }^{\circ} 167$. Instituto de Investigaciones Agropecuarias (INIA), Santiago, Chile.

Ruiz, R., y Araos, F. 1978. Contenido de potasio intercambiable en suelos de Copiapó a Curicó. II Simposio Nacional de la Ciencia del Suelo. Universidad de Chile, Facultad de Agronomía, Santiago, Chile,

Saavedra, G., Corradini, F., Antúnez, A., Felmer, S., Estay, P., y Sepúlveda, P. 2017. Manual de producción de lechuga. Boletín INIA N³74. Instituto de Investigaciones Agropecuarias (INIA), Santiago, Chile.

Sadzawka, A., Carrasco, M., Grez, R., Mora, M., Flores, H., y Neaman, A. 2006. Métodos de análisis recomendados para los suelos de Chile. Revisión 2006. Serie Actas INIA N³4. Instituto de Investigaciones Agropecuarias (INIA), Santiago, Chile

Salazar, O., Balboa, L., Peralta, K., Rossi, M., Casanova, M., Tapia, Y., et al. 2019. Effect of cover crops on leaching of dissolved organic nitrogen and carbon in a maize-cover crop rotation in Mediterranean Central Chile. Agricultural Water Management 212:399-406.

Sosa, A., Ruiz, G., Padilla, J., Etchevers, J., Castellanos, J., y Robles, R. 2017. Curvas de acumulación de nitrógeno, fósforo y potasio en lechuga (Lactuca sativa L.) cv. Coolward cultivada en invernadero en México. Informaciones Agronómicas de Hispanoamérica 25:23-28.

Sylvestre, T.B., Braos, L.B., Batistella Filho, F., Cruz, M.C.P., and Ferreira, M.E. 2019. Mineral nitrogen fertilization effects on lettuce crop yield and nitrogen leaching. Scientia Horticulturae 255:153-160.

Tosti, G., Farneselli, M., Benincasa, P., and Guiducci, M. 2016. Nitrogen fertilization strategies for organic wheat production: Crop yield and nitrate leaching. Agronomy Journal 108:770-781.

Uribe, H., Pérez, C., y Okuda, Y. (eds.) 2005. Recursos hídricos y manejo del agua para un desarrollo sustentable del secano. Boletín INIA N${ }^{\circ} 23$. Instituto de Investigaciones Agropecuarias (INIA), Chillán, Chile.

Walters, D.R., and Bingham, I.J. 2007. Influence of nutrition on disease development caused by fungal pathogens: implications for plant disease control. Annals of Applied Biology 151:307-324. 